\title{
Developing an English Literacy Training Program for the Work Context: The Trainer-Researcher Reflection
}

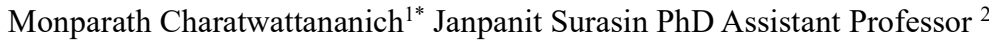 \\ 1. International Graduate Human Resource Development (Teaching English as a Global Language) \\ Burapha University, Chonburi, Thailand \\ 2. Department of Asian Languages and Cultures, University of Wisconsin-Madison, \\ Madison, WI 53706 USA \\ *plakadd@gmail.com
}

\begin{abstract}
The aim of this Doctoral research was to explore with the developing of training- research process of an English literacy training program for engineering staff for the work context and to determine how the researcher-reflection effects the training program. The Instructional System Design (ISD); ADDIE model was used as a framework for developing the training program. The sequencing process of ADDIE; Analysis, Design, Development, Implementation and Evaluation was operated in two phases as to seek for a more precise and reliable training program development. The researcher took two roles of an English language trainer and a researcher. The trainingresearch results found that engineers' skill needed were listening, speaking in work context, and presentation skills that they could learn and apply right at work and they preferred practicing and activities rather than listening to the classroom instructions. The training was a practice-based design using a combination of work-related content / topic and material developed to address the authenticity of work context. The peer-peer interaction helped participants gaining more confidence and learning outcomes. The research suggested that trainer's ability to facilitate and stimulate the practicing opportunities resulted in learner's speaking skill improvement.
\end{abstract}

Keywords: ADDIE, work context, authenticity, global English

DOI: $10.7176 / \mathrm{JEP} / 10-24-13$

Publication date: August 31st 2019

\section{Introduction}

The literacy deficits could be an employability barrier, hence there is a need for expanding training for workers through their workplace literacy training program. The workplace literacy training has been promoted nationwide in the USA and in other nations to respond to the literacy challenge. Adult educators have taken various approaches designing and implementing workplace literacy program as to narrow down the gaps. As such, workplace literacy training program has been developed and evolved constantly to meet the people and the world changes. The authentic and learner-centered are the key to empower participants (Jurmo, 2004). The declaration of the UN Literacy Decade (2003-2012), UN has been a forefront to promote literacy in youth and adult, in industrialized and developing countries via promoting the literacy training program throughout academic institutes, nongovernmental organizations, communities and national governments. The campaign emphasized that literacy can be acquired and applied in daily life and can be anywhere: at home, in the classroom, in the workplace or in the community. A Greater attention has also been paid to the language or languages in which literacy is learned and practiced (UNESCO, 2005; UNESCO, 2008). However, in the globalization era, the rapid changes in the world of work and the multimodal literacy and complexity are increasingly required. The basic literacy skills of reading, writing, grammar and spelling are no longer enough for employee to survive in the 21 st century workplace. The employee needs to take opportunities for self-development while it is also the employers' job responsibility to structure specific workplace literacy training, complex literacy skills, and high-level cognitive learning that help their employees to successfully communicate and be able to initiate into the way language works in their workplace context (Adoniou, 2016).

English language has been widely used in a global business and is used as a major language of international business, sciences and the professions (Kitao, 1996). Both form of verbal and written English communication are used as a global language between different professions from different entities. Global language is a language that genuinely develops a special role that is recognized in every country (Crystal, 1997). The special role clearly helps in defining the world and global language in terms of people of other countries needs for an official language that 
can be used as a medium of communication, and it is English language that plays such role. For instance, the engineering specification is written in English as it is the shared textual data among Thai, Chinese, and colleagues in the USA or in Mexico or Europe who work on the same engineering data. Hence, such workplace context and engineering profession demands are inevitably stimulating engineers to be well qualified with English language and communication skills because there is a need for using English as in a global context for global communication. English literacy training; therefore, is deemed to be initiated differently to meet the contextual need as the most. The English literacy training for work context has its significance because such training has not been taught in school; it must be acquired and practiced in the workplace and for work context.

\subsection{The problem}

Many studies found that engineering graduates have not been well qualified in English language and communication skills when compared to the needs of industry internationally (Riemer, 2002). As in the same situation of Thailand, where each institution of higher education is required to implement national curriculum standards for English as Foreign Language (EFL) literacy instruction to fit their institutional goals (Riamliw, 2013) but there may be a literacy gap between learning English literacy in school and English literacy required in the workplace. The workplace and engineering education have been facing challenges in implementing effective program to improve English language and communication skills. This challenge is also found with Thai engineering graduates. There was feedback from industrial sectors complaining about the gap between what English is taught in university class and what is used in the workplace communication (Rajprasit, Pratoomrat, Wang, Kulsiri \& Hemchua, 2014). In real world of work, engineering work context involves English language, strong communication skills and a global professional skills of engineering solution in their global community. So, the English skill gap would need to be identified and amended with improvement for the work context.

In this present research, the researcher had acknowledged the same English skill gap in employees. As a Recruitment and Training manager hired in year 2014 at this research site, the role also entitled a training manager to be the company certified trainer to conduct in-house accredited corporate training course as well as developing necessary in-house training program. There were requests for English language training from many departments via the annual performance review and individual improvement plan. The observation had been taken and it was well aware about the employees' English skill gap. For further preparation, the past records of English language training expenses during the year 2008-2014 was reviewed and the big amount of spending was made to several English language training centers on General-English course for employees at the officer level. However, a few groups of workforces: engineering and human resources staff were left out. That was because some of engineers were newly joined while many were not available to attend the course and human resources staff did not present their needs at that time.

According to the expense record, the justification whether a 'purchase' English training program or the 'self-design' should be considered. On the basis of 22 years of work experience in the electronics industry and engineeringbased products, the researcher had gained working experiences with engineers from various functions in a few leading multinational companies located in Thailand, and another base of English language proficiency in the context and training skills, the researcher decided to take charge in providing the in-house English training program. So, prior to the final decision to conduct this training-research, the self-design courses were simply developed for an in-house English language training. The needs survey on English language training was conducted and on one specific aspect about the employee's attitude towards learning English with non-native trainer and commitment to learn English. Most of them said that they preferred learning with native-speaker but due to work responsibilities, they might not commit to the absolute participation. decided to lower the curiosity about the 'self-design' program, the English training class was launched an opened for officer level. So, in year 2015, the first three group of diverse participants were officer level from various functions as well as some engineers. The groups were justified based on the placement test: novice, intermediate and intermediate high per ACTFL proficiency guideline 2012 (ACTFL, 2012) The course covered basic four skills and a combination of lessons selected from standard English text books and with selective work-related topic. In 2016, another fundamental English course was set for three production clerks as their request to better their basic speaking and writing skills. Lastly, in 2017, another English presentation skill was conducted to five section managers from production and quality assurance function to prepare and improve their presentation skill in English in the Annual Fiscal 2018 meeting.

The quality workforces largely determine organizational competitiveness, customer satisfactions and its long-term economic growth. As a critical mission, considering for an English training program was necessary. Yet the employee's commitment to the class attendant was vague, the curiosity of developing a 'self-design' English 
program for in-house use was an alternative path but could be possible. Nevertheless, the study of training-research, especially for the English literacy program for work context and in a workplace in Thailand is infrequent. So, the researcher had a curiosity of how a self-design program would serve the needs of the work context and what the training program should look like. Yet the standpoint was the most authenticity that responds to the work context. The training-research to be presented in this article is a narrative data represents the trainer-researcher's reflection on the process operated under the training program development together with the representing of the overall research discussion. Hence, the training-research project was pursued from start of the training program through the Instructional Systems Design (ISD): the ADDIE model to tackle each step. Two guiding questions assisted the focusing of this research and guided questions were:

1.What are the process of developing a self-design English training program to serve the needs of a workplace context?

2.What are the reflection(s) of novice trainer-researcher towards the training program process and does the process promote professional development?

\section{Literature review}

\subsection{Literacy links up to workplace literacy}

The workplace has been increasingly filled up with high technology equipment, dispersion of production process, a decentralized, flexible automation systems of production model for maximizing productivities. The hall mark of such arrangement is fewer job classification with workers expected to assume greater responsibilities (Bhattacharya, 1997). The workforce should be ready to penetrate new markets, execute tight production schedules or launch new innovative units on time needed. The organizations then have created necessary technical skills training, and soft skills for managing people while compulsory skills such as computer and language skills have also been provided. This conclusion was drawn from actual practices as in many countries where the organizations employ several migrant workers and English is used as working language, the English literacy training would be necessary. In Australia, the LLN program (Language, Literacy and Numeracy), deemed the valuable returns from the training program, both organization and workforces would gain productivity, safety, quality, communication, compliance, further training and promotion which is the employee's career growth (Brown, Taylor, McKenzie \& Perkins, 2015). The Singaporean Government dedicatedly and fully supports workplace literacy improvement for employees and employers. The workplace literacy has it based with the "Skills Framework" which is an integral component of the Industry Transformation Maps (ITMs) and co-created by Employers, Industry Associations, Unions and Government for the Singapore workforce (Singapore Workforce Skills Qualifications, 2017). Such work collaborations have proved enhancing the relevancy of workplace literacy and effectiveness of the program that serve both employer and employee and work context, thus, ultimately grows country's economy. Hence, the replicating idea of developing an in-house English training program that addresses the workplace context and learner's needs and by the insight person who understands the context and ability to be a subject matter trainer could enhance desirable outcomes for the organization and of employee's literacy improvement.

\subsection{The needs for English literacy for engineer in a global work context}

The globalization enforces all professions to develop their global capabilities and the engineering profession in one of those professions. Engineer is also required to be prepared to become a global engineer. As in the $21 \mathrm{st}$ century towards the next decade, engineers will be influenced and nurtured by the much more rapidly changing and increasing use of advanced technology, global mobility and multicultural complexity. They need to be able to work with multi-disciplinary teams and understanding of professional and ethical responsibilities. They need more than just the hard skills in engineering but the soft skill of English language and strong communication skills as well as a global professional skill of engineering solutions in a global context (Riemer, 2002; Patil, 2005). In engineering communication, as Nguyen (1998) reported, engineer should understand the cultural differences showing appreciation and acceptance terms commonly used in engineering field and the engineering jargon, an informal language commonly used in engineering. This challenge has also been found with Thai engineering graduates. There was feedback from industrial sectors complaining about the gap between what English is taught in university class and what was used in the workplace communication (Rajprasit, Pratoomrat, Wang, Kulsiri \& Hemchua, 2014). Based on the researcher's work experiences it could corporate with this finding about the 'gap' because there are lots of complication task such as dynamic changes during conversation among several 
parties in the project meeting in which the knowledge from university class can only be little applied in the real situation. The applied knowledge to any solutions may vary from one workplace to another and the skills may be applied differently. Some employers have different requirement levels on each English proficiency skills in the engineers. These employers paid highest attention to reading, listening, writing and speaking respectively because of their industrial or context differences (Sureeyatanapas, Boonma \& Thalangkan (2016). In the same stance, in Malaysia the engineering-based chemical companies would need more oral communication and communication skill rather than the written communication (Kassim \& Ali, 2010). While Spence \& Liu (2013) found that the process integration engineers (PIEs) in Taiwan need writing and reading emails on daily basis and need to use English speaking and listening when attending meeting or monthly presentation or conference call of only once a month. Based on these studies, it could be seen that engineering profession in many countries needs to become more productive in English language, yet varies in each skill differently as their context and market driven. So, the understanding of real needs of their workplace context could promote the quality of university curriculum design or training program development in private organization.

\subsection{The framework for developing the training program: ADDIE Instructional Systems Design}

The heart of developing a training program is the designing of instruction as to improve human performance. It implies that the systematic process of designing the instructional plan helps related persons in the process, especially with the instructor and the learner achieved individual goal (Smith \& Ragan, 2005). The ADDIE model presents a thorough of its five phases of Instructional Systems Design (ISD) and it has been described as the most commonly used training model for the workplace (Holden, 2015). The ADDIE is an acronym referring to each step of Analysis-Design-Development-Implementation-Evaluation. ADDIE serves the most contextualized instructional design in the sense that ADDIE process facilitates the ability of the instructional plan to progress the learner while increasing the fidelity between the learning space and the performance space, such ability then, increasing the potential for success. Moreover, it is rather used as broad process in which the program designer could be more malleable to explore appropriate action/ strategy that match such key process. The instructional design advances high reliability between learning environments and real work settings. High fidelity among learning and work environments is achieved by instructional design through an emphasis on measurable outcomes (Branch, 2010). Furthermore, the alternative of applying the linear sequence of ADDIE process to address activities of each step and with the clear identification of the measurable outcomes, the information could flexibly be used in the later stage(s) of another round of A-D-D-I-E to see the wholistic improvement or changes of the whole process. The ADDIE model does not only serve the purpose of designing a training program but also for content of educational level. In Thailand, Hiranrat, Ruksasuk, \& Chaijaroen (2016) studied the process of applying ADDIE model for their contents design of an e-learning tool for M.5 (Grade 11) English subject, hence the only AnalysisDesign-Development step for their initial design and development purpose whereas the following step could be performed later on. In the similar research, Nichols \& Greer (2016) studied with the use of ADDIE for developing an E-learning course for the online Information Literacy Course in the American Association of College and Universities. They used full cycle from the phases of Analysis, design, development, implementation, and evaluation. The used of ADDIE model was strengthen student engagement and develop cross-disciplinary conversations about students' information literacy learning. With this system design, they could easily set timeline of whole steps; Analysis-Summer 2014, Design and Development-Fall 2014 and Implementation and EvaluationWinter 2015. These studies revealed the partial use of only three steps or five steps of ADDIE to serve their purposes. It demonstrated the exemplar of ADDIE as flexible guideline for building training and performance support tools (InstructionalDesign.org, 2019). Thus, applying ADDIE model in this training-research supported 'best fit' framework for a contextualized English literacy training program in which the thorough operation of each step had been emphasized and engaged by the same person of training program developer and the trainer and for the measurable outcomes; cognitively and affectively.

\section{Research Methodology}

\subsection{Conceptual Framework}

The conceptual framework in this training-research relied on the ADDIE framework (Kurt, 2017) and was operated in two phases, so the conceptual framework can be presented as in below figure: 


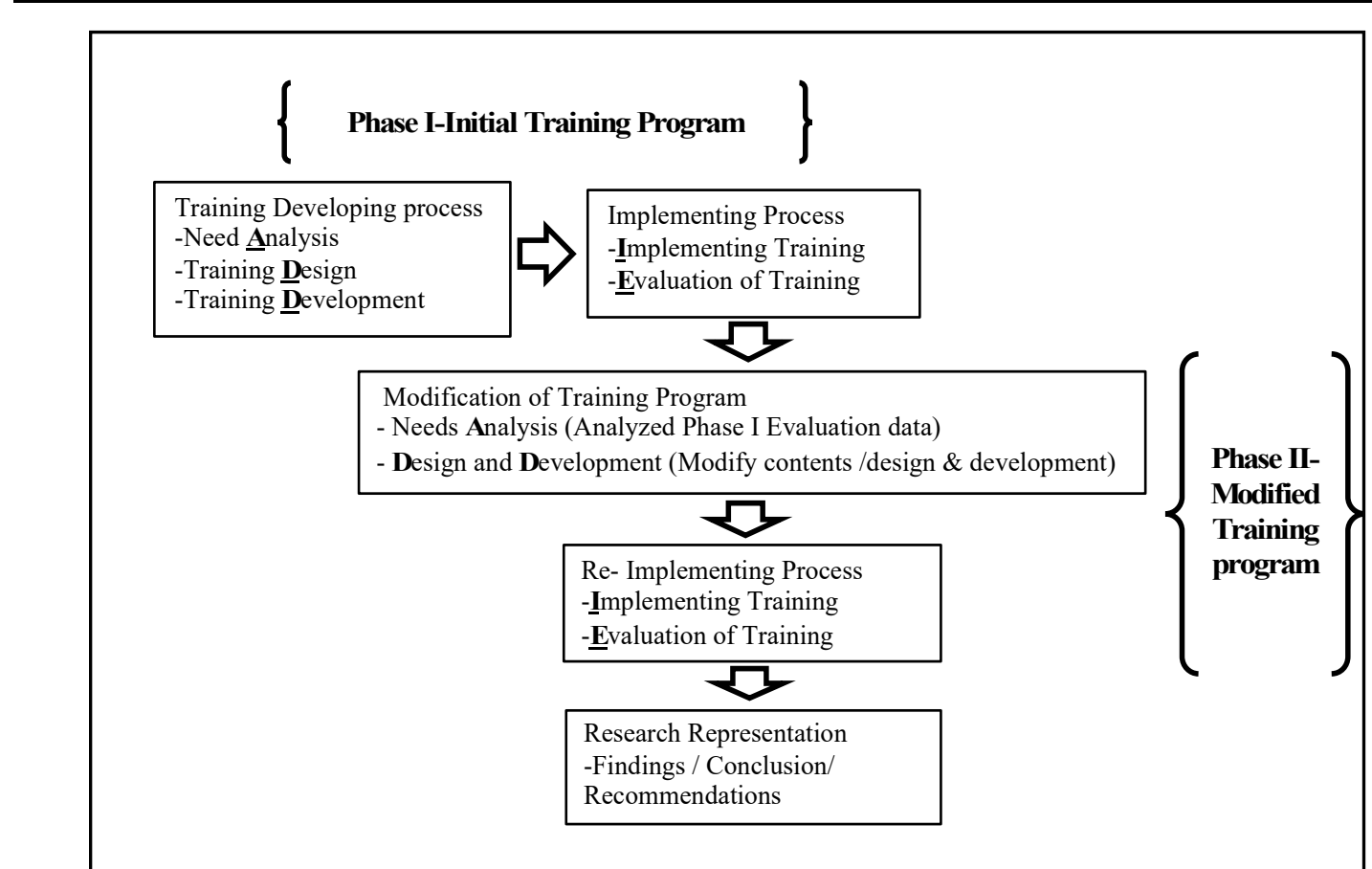

Figure 1: Conceptual Framework-Researcher's training program design based on ADDIE model

The figure 1 illustrates the framework for a developing process of the training program. The process is orderly conducted in two phases: Phase I-Initial training program operates with two major steps 1) Training developing process which consists of need analysis step, design step and development of material step and 2) Implementing process which consists of the implementing of the training and evaluation of training. In order to move on to the Phase II-Modified training program, another cycle of the same process in Phase I was recurred by using the results data in Phase I to analyze and interpret in to another set of data for Phase II and it is called the modification of training program step. Then Phase II process carried out to the final process and conclude into overall research report and recommendations.

\subsection{Methodology}

In this training-research agenda, there were two items: the developing of training program research and the creating of the researcher's reflections in to the whole research results. The developing of training program was conducted in two Phases: 'Phase I- The initial training program' and 'Phase II-The modified training program'. The ADDIE model was applied as a research framework for developing of training program. The ADDIE model was sequentially conducted from Analysis-Design-Development-Implementation-Evaluation in two phases of the training program session. The sequencing of the process is described as follow:

- Analysis was the very first step undertaken for finding need information from the participants. The indepth interview and document analysis were used as instruments. The interview protocol question was created and contained questions to understand 1) participant's job details 2) self-assessment of current English skill 3) needed skill to improve 4) opinion about variety of accent (global English) and 5) training / learning method. Nineteen key informants took the interview and voice recording. Voice data was then proceeded through qualitative data analysis of transcribing-coding-categorizing for theme or pattern as sentences summarized (Saldana, 2015). The work-related document: job description, emails, project presentation and the Appropriation Request (AR) document were collected as document analysis and interpreted for theme or pattern then merged with the interview data as a set of need data for the next step of Design.

- Design was a step of designing the program's objective or goals based on the need data, specified evaluation tools, training schedule, and teaching/ learning material plan. In this process, considering the suited design and development for the participant who is the adult learner is important.

- Development was the activities for specifying training contents responded to the objectives and needs, searching of audio-visual material, preparing training material, hand-outs or power point slides and initiating of the instructional plan. This process took place as a parallel production along with the Design 
process.

- Implementing was the delivery of the training per instructional plan. During the implementing step, a classroom video recording was recorded and the trainer-researcher' reflective journal was written as part of the training and research instrument.

- Evaluation contained formative assessment which was a during implementing process assessment as to check the feedback during class, and the summative assessment which was a formal assessment using the Kirkpatrick's four-level assessment. The Kirkpatrick's four-level was used as to measure difference aspects include:

Level 1-reaction assessed how the learner perceived with the training program in several aspects such as affective reaction, instructor reaction or program delivery reaction. So, the trainer-researcher created an instrument to assess this level. In the Phase I, the questionnaire assessing macro skill, micro skill, and teaching method via 3-point Likert scales was used together with open-ended questions for writing. In Phase II, the short interview question to understand about how and what did the participants learnt and what skill they could apply at work.

Level 2-learning assessed knowledge and skills the participants learned from classroom. The short test / quiz was developed for testing of learning. Learning score was not the critical judgement of the working adult learner but the trainer to Each test/quiz was developed per each individual Phase I and Phase II training and learning content sequentially.

Level 3-behavior assessed the behavioral changes observed from classroom and through the video recording review and researcher's reflective journal. The behavior observed in Phase I was recorded as a behavior baseline then compared to the behavioral changed or improved in Phase II.

Level 4-results were the overall outcomes interpreted by the trainer-researcher as the training program assessment. In Phase I, the level 4-result was the integration of level 1 analysis with the interpretive of level 2 together with behavioral baseline data of level 3 and combined with the researcher's reflection to become the 'overall Phase I training results. Then this 'overall Phase I training results' was used as the need analysis data of the Phase II design step. Later in Phase II, the same integrating process was conducted; the interpretive of level 1 combined with level 2 and level 3 interpretive and combined with researcher's reflection to make level 4 results.

The trainer-researcher's reflective journal was written after every class-hour and were interpreted and narrated in the reflection aspects for the use of training program evaluation or adjustment data and as reflections that impact or promote the professional development.

\subsection{Participants/ Research site and work context}

Engineers were purposefully selected as participants in this research. They were information-rich with respect to various branches of engineering of diverse purposes of need and they were the biggest group of employees; 35 persons as of 2018 employee record. The engineering functions are for example; manufacturing engineer, quality engineer, environmental engineer, safety engineer, design engineer and product engineer. Their work responsibility identified the most need for English training. compare to others. The total of 20 engineering staff signed the consent letter and agreed to participate in the program. Later due to employee resignations and dropouts, there were seven engineers from the same group participated in Phase II.

The research site is a manufacturer of scroll compressor for refrigeration and air conditioning system and solutions, located in Rayong province, Thailand. The research site is a multinational company (MNC) under the corporate governance governed by the headquarter in St. Louis, Missouri, United States. The major customers are in Asia Pacific region, North Asia, Middle East and Africa (MEA) and Australia and New Zealand. The company exports $80 \%$ of the products to these regions with $20 \%$ domestic sales. The context was the context of real work experiences and constraints the participants have faced when using English language in their work activities with other global team, yet there is only one American Vice President stationed at this research site. The equipment setup in the factory requires intensive care due to the age of the machines. They responded for several types of machines: semi-automation and full automation, small jig fabrication as well as the robots. The tight production schedule or unpredictable machine broke down may impact some participants' attendance or might impact the whole classroom environment. 


\section{Findings}

The findings presented here respond to the guided question of how to develop a self-design English training program for the work context. So, the process of developing the training program is described per each ADDIE step as below:

\subsection{The developing of training program process}

The findings start from the Phase I-Initial Training Program process which was taken place from May-September 2018. The Analysis step found that the engineers in this research site had shared job details to manage and control existing and new products and the production process, regardless of different product type such as rotor, motor, compressor or CDU (Air conditioner Condensing Units). Some engineers need to attend conference call on weekly or monthly basis while some need more email writing than meeting in conference. This type of need was interpreted into the designing of topic-based that related to work and selection of activities that imitated the work situations. The reviewing of work-related documents helped understand the participant's writing skill deficits and the frequent errors such as the using of two auxiliary verbs or infinite verb in the same sentence 'should be have/ I am is initiator'. The interview data also brought in the information of speaking and listening skill deficits. The participants admitted that they truly needed those skills in their work and many participants admitted that they are frustrated when they cannot remember the vocabularies and causing difficulties to produce a complete sentence. Several engineers mentioned that they have no confidence to speak out as they are afraid of making mistakes. An excerpt from an interview with Mr. CT clearly expressed his feeling about his deficit skills and needed skills:

Processing the proper sentence in my brain is a problem, I do not have proper vocabulary and grammar. It is just like the production process in my work, when I do it more frequent then I can be more fluent. I can only process simple sentence but if I want to speak more formal and with politeness, I find myself in difficulties to put these words in order

The interview question about variety of accent, every engineer acknowledged that they could feel the effects of accent in their work life. Some engineers believed that having proper accent would help the listener understand the speaker's intention, yet one engineer said that his Thai-English accent always caused confusion. Nevertheless, one engineer clearly stated his feeling and he seemed to understand that he has been in the global English immersion at work. An excerpt from the interview with Mr. ST is as below:

As an English language user, I used to think that I have to be like native-speaker accent. I felt that my attempt fails because I spoke very clear English, but they did not understand me. At present, I realized that I have worked with a lot of multinational colleagues, both internal and external counterparts. They speak different Englishes accent as well. This is the reason I am brave enough to communicate more in my global work community.

Another analysis finding was when engineers mentioned about their preference with practicing or having activities in classroom rather than purely listening to the instruction because it might made them sleepy and get bored while some engineers favored to listen to the instructions, especially with grammar learning. These findings were used as Analysis step and they become needs data for the following step of Design and Development

As a trainer-researcher, the role of program designer must also be taken. The researcher put effort on a number of searching and reading the 'how to teach ... skill' from many academic websites, and spent time on selecting YouTube clip of different teaching techniques that supported skill content and language content designed. The objectives of the Phase I aimed at giving important knowledge that participants need to understand for amending their previous knowledge while improving deficit skill then to improve their needed skill such as: vocabulary knowledge and vocabulary expansion that helped them increasing their vocabulary bank. The better understanding of basic sound in English word which causing hardship to understand variety of accent as well as the correct way of composing sentence were designed and developed in the Phase I. In summary, such objectives led the instructional plan towards the training direction and influenced types of training material to be developed. The data analysis results reflected in the Design and Development of training program objectives and documented in the Phase I-Training program description and is presented in the table below: 
Table 1: Phase I-Training program description (Brief details)

\section{Training Goals}

This first session of 18 hours training program is developed to respond to the in-house needs for refining English communication skills of the engineering staff. The engineers will be guided to strengthen their listening and speaking abilities with the integrated English skills from their work experiences

\section{Training Objectives}

1. Recognize main action verb vocabularies related to work context and able to use and produce vocabularies in work context

2. Develop vocabulary learning strategies, able to apply in listening comprehension and in 3minutes project presentation

3.Pronounce and read aloud words and phrases an international intelligibility sound

4. Define and recall basic elements of simple and compound sentence, able to use it orally and in writing

5. Construct simple conversation, use correct language structure and discuss confidently in classroom environment

Training schedule of total 18 hours

From September 3 to October 2, 2018, Monday to Friday at 12:30-13:30, at Training Service Center.

The above Table 1 identifies core information extracted from the Phase I- Training Program Description identified training goals, training objectives and the training schedule. The need data was also interpreted into the training content and for specifying activities and material selection/ design. Upon completion of the training program description then the instructional plan was parallelly initiated and to be used for developing content, material and classroom management agenda. The Phase I-Instructional plan is shown as below:

Table 2: Phase I-Instructional plan of 18 hours

\begin{tabular}{|c|c|c|}
\hline Hour & Content/ Training description & Core Training Activity \\
\hline $\mathrm{H}-1$ & Language/ Verb of work vocabulary & $\begin{array}{l}\text { Vocabulary knowledge-work context } \\
\text { (job description) }\end{array}$ \\
\hline $\mathrm{H}-2$ & Language/ Verb of work vocabulary & $\begin{array}{l}\text { Vocabulary knowledge/speaking } \\
\text { practice }\end{array}$ \\
\hline H-3 & Language/Vocabulary expansion & Prefix-Suffix/Thesaurus \\
\hline $\mathrm{H}-4$ & Language/Sport Vocabularies & $\begin{array}{l}\text { Vocabulary expansion (daily life } \\
\text { context) }\end{array}$ \\
\hline $\mathrm{H}-5$ & Language/Sport Vocabularies & $\begin{array}{l}\text { Speaking practice on Sport } \\
\text { Vocabularies }\end{array}$ \\
\hline H-6 & Language/Vocabulary retention-recognition & Bingo game-Vocabularies \\
\hline $\mathrm{H}-7$ & Skill/Writing-Speaking-Synthesizing & $\begin{array}{l}\text { Work related Problem Solving-pair } \\
\text { work }\end{array}$ \\
\hline $\mathrm{H}-8$ & Discourse/ Speaking-Critical thinking & $\begin{array}{l}\text { Group discussion } 2 \text { topics: Smart City } \\
\text { and Social Networking }\end{array}$ \\
\hline $\mathrm{H}-9$ & $\begin{array}{l}\text { Language/Phonemic-consonant-vowel- } \\
\text { minimal pair }\end{array}$ & Phonemic instruction \\
\hline $\mathrm{H}-10$ & Language/Intonation-stressing & Listen to YouTube clip/ practice \\
\hline $\mathrm{H}-11$ & Language/ Pronunciation & $\begin{array}{l}\text { Reading aloud of work-related } \\
\text { content: Scroll compressor and } \\
\text { Hermetic }\end{array}$ \\
\hline
\end{tabular}




\begin{tabular}{|l|l|l|}
\hline Hour & Content/ Training description & Core Training Activity \\
\hline H-12 & Language/Simple sentence & $\begin{array}{l}\text { Explicit instruction-YouTube content- } \\
\text { practice writing/correcting frequent } \\
\text { errors }\end{array}$ \\
\hline H-13 & Language/Compound sentence & $\begin{array}{l}\text { Explicit instruction-YouTube content- } \\
\text { practice writing }\end{array}$ \\
\hline H-14 & Language/Present and Past Simple tense & Listen to YouTube Clip/ practice \\
\hline H-15 & Discourse/ Presentation & Presentation practice \\
\hline H-16 & $\begin{array}{l}\text { Skill/ Listening to Thai-English accent } \\
\text { H-17 }\end{array}$ & $\begin{array}{l}\text { Practice listening to Thai-English } \\
\text { accent + critical thinking skill }\end{array}$ \\
\hline H-18 & $\begin{array}{l}\text { Language/Basic Tense use for work present }+ \\
\text { present progressive +past simple and present } \\
\text { perfect tense }\end{array}$ & $\begin{array}{l}\text { Specific tense needed to know for } \\
\text { work-authentic material from work to } \\
\text { practice }\end{array}$ \\
\hline H-19 & Test/Quiz and Evaluation process & \\
\hline
\end{tabular}

As shown in Table 2, the Phase I-Instructional plan was designed and developed for Phase I training program, the main content was language content which was the fundamental of skill deficits and needed skills responding to participants' need. The trainer made use of this instruction plan by following the content and activities specified. The plan was also distributed to the learners to make sure of their awareness. The following step was the Implementing of the training program and it was the delivery of instructional plan and the act of the trainer in managing the classroom environment. The official email of training invitation was sent to all participants who signed the consent form and agreed to participate in the training-research program, with the cc to their direct supervisor or manager for acknowledgement because the training hour took half hour of employee's lunch time and half hour of company's working hour; at 12:30-13:30 on Monday to Friday.

On the first Implementing hour, there were 20 participants walked in to the training room, one engineer cancelled his participation, and another one substituted. The researcher had realized a challenging of a high diversity group and a teaching anxiety at the very first hour. The classroom type seating was set and it was difficult to re-arrange due to the lesson plan relied more on the chalkboard method. The used of power point slides as material training and pure instruction in the very first week was not a good training technique, yet the participants are familiar with this type of 'traditional company training' setting. However, as trainer-researcher, it was preferable to re-arrange the seating type to accommodate the classroom environment as the most. The video recording was set to automatically taken in every class-hour for the purpose of participants and trainer-researcher's behavioral observation for the evaluation and data analysis. Key results found in the implementing process was the low efficiency when integrating too many contents and activities to a high diversity class. The training could not be too fast or too slow. Each individual participant had their own objectives as adult learner's characteristic and some may not think it is necessary to learn everything the instructor planned to give, so there was a distraction and affect to their class attendances.

After the completion of 18 hours, the following step of Evaluation was conducted at the end of Phase I. There were 11 participants attended in the evaluation process. The evaluation result was important as the need data for inputting in the Phase II analysis step. The reaction evaluation revealed opinions that the participants were excited to learn new skills such as prefix-suffix and learned how to use Thesaurus that helped them expand vocabulary knowledge rather than just using the Google Translate tool. The practicing of basic phonic, stressing and intonation helped them better understanding about varieties of accent and how to improve their proper sound making. The result of macro skill showed that they still did not improve listening, speaking nor writing skill and they moderately learned. For micro skill, they could improve their vocabulary learning. The open questions described that participants proposed only three hours per week and they wanted to focus on a lot more speaking skills practice because they felt that imparting as normal lectures might not help them much in the just one hour. However, from the content testing, it was correlated with other results because they need to practice writing simple sentence. The important findings about behavioral observation were the positive behavior of 'enthusiastically turn to peers or group when paired-up or grouped-up' and for the low proficient learners they 're-think and try for longer complete sentence'. Meanwhile, participants showed negative behavior of 'inattentive learning manner' and 'always play 
with phone off-task'. Those who showed such behavior were signaling their dropouts after 2-3 weeks. The final process of Phase I finished at this stage and the process of transitioning into Phase II happened right at this point. The integrated evaluation data from Phase I combined with classroom observation and researcher's reflective journal became need data of the start of Phase II.

The Phase II-Modified Training Program then began from September 2018-January 2019 and the first step of Analysis was a transitioning set from Phase I data as aforementioned. The data of needs: speaking skill in the work context, improving listening skill and simple sentence writing as well as the request for class-hour changing were the needs to be used in the Design and Development of Phase II. The researcher then interpreted the needs into the Phase II-Training Program objectives and the instructional plan once again. The detail is described in the table below:

Table 3: Phase II- Training program description (Brief details)

Training Goals

This Phase II training program is designed for improving of the training outcomes of the Phase I of English literacy training program. This Phase II program has its goals to improve Engineering staff of their listening, speaking discourse and writing skills. In this session, the engineers will be guided to engage with practice-based of these skills in real work context in-classroom and off-classroom.

Training objectives

1.Listen and identify gist, specific information and details information of the medium speed level of daily life conversation during class practices and in the work context performance

2.Converse and make discourse conversations in a communicative language structure and discuss confidently in classroom environment and in work presentation

3.Write simple and compound sentences or phrases using an intelligible English to convey communicative meaning in work writing context

4. Integrate listening, speaking and writing skills into the global work context.

Training schedule of total 18 hours

November 19-December 28, Monday to Wednesday, at 12:30-13:30, at Training Service Center.

As shown in Table 3, the training goal aimed at further improving skills lack from Phase I. The key change was also with the class-hour that addressed participants request in which the researcher mutually agreed to change as it was valid for acceptance. These changes could be positive impact with the instructional plan and the Phase II Instructional plan is presented as below:

Table 4: Phase II Instructional plan for 18 hours

\begin{tabular}{|l|l|l|}
\hline Hour/WK & Content/ Training description & Core Training Activity \\
\hline H-1/Wk1 & $\begin{array}{l}\text { Language/ simple and compound } \\
\text { sentence } \\
\text { H-2 }\end{array}$ & Pair work exercise drill \\
H-3 & Language/ past tense & Pair work exercise drill \\
H-4 & Discourse/ Project management & $\begin{array}{l}\text { Pair work exercise drill } \\
\text { Group work of three person }\end{array}$ \\
\hline H-5/Wk2 & Skill/ Listening Sub-skill & Listening for GIST \\
H-6 & Skill/ Listening Sub-skill & Listening for Specific info \\
H-7 & Skill/ Listening Sub-skill & Listening for Inferring + detail \\
\hline H-8/Wk3 & Discourse/Functional English knowledge & Pair work learning \\
H-9 & Discourse/Functional English writing & Pair work -script writing \\
H-10 & Discourse/Functional English speaking & Pair work -role playing \\
\hline H-11/Wk4 & Discourse/Presentation basic rules & Pair work- power point writing \\
\hline
\end{tabular}




\begin{tabular}{|l|l|l|}
\hline Hour/WK & Content/ Training description & Core Training Activity \\
\hline H-12 & $\begin{array}{l}\text { Discourse/Presentation preparation } \\
\text { Discourse/Presentation practicing } \\
\text { Discourse/Presentation practicing } \\
\text { (cont'd) }\end{array}$ & $\begin{array}{l}\text { Pair work- power point writing } \\
\text { Pair work- duo presenting } \\
\text { Pair work- duo presenting }\end{array}$ \\
\hline H-15/Wk 5 & $\begin{array}{l}\text { Discourse/Storytelling 'who is the busiest } \\
\text { man' } \\
\text { Discourse/Storytelling 'find solutions to } \\
\text { the busiest topic' } \\
\text { Hiscourse/Storytelling 'tell the solutions' } \\
\text { the judge to reward for the best solution } \\
\text { of the pair ideas }\end{array}$ & $\begin{array}{l}\text { Individual tells story to peers } \\
\text { Pairing who tells the same } \\
\text { busiest story' used 4Ms criteria } \\
\text { and the pair works for solutions } \\
\text { Each pair tells solution, the } \\
\text { judge to reward the best idea }\end{array}$ \\
\hline H-18/Wk 6 & $\begin{array}{l}\text { Discourse/ Storytelling to group 'New } \\
\text { Year bucket's list' }\end{array}$ & $\begin{array}{l}\text { Individual tells to group on the } \\
\text { New Year bucket's list, trainer } \\
\text { stimulates group discussion }\end{array}$ \\
\hline H-19 Test/Quiz/ Evaluation process $\rightarrow$ Test and conduct face to face short interview \\
\hline
\end{tabular}

As above Table 4, the instructional plan as a 'block lesson' of three hours per week allowed effective planning of one content that included explicit teaching, participant practicing during the remaining hours of that block week. This instructional plan reflected the fact that pushing too broad contents and activities in one day was not a good plan. The block lesson eased contents development, material and selecting of work-related topic and a contentrich/ skill-rich YouTube clip, yet this development activity remained the critical task and time consuming for the program. Searching for the grammar exercise hand-outs created a wonderful result to both trainer and learner based on the practice-based method. When the instructional plan was ready to use, the training invitation for the Phase II training was made and the first hour of implementing of the training resumed.

The first hour of Implementing the Phase II program started with the total of seven consistent participants; those who always show enthusiastic to learning. This was the best chance to arrange classroom seating type as single square or round table that serves the lesson plan and accommodate the number of participants. The participants were more participative and fully engaged in the class environment. The video recording was set to automatically taken in every class-hour. The reflective journal was even more critically written by the researcher. However, there was unpredictable plant working day shifted, then the training schedule was also pushed back to complete in January instead of December plan.

By the end of implementing of the training, the following step of Evaluation was operated. All seven participants took the test and participated in the evaluation process of a short interview. The training results observed from classroom environment showed that participants better comprehended with the correct sentence structure as well as the used of proper simple and past tense. They understood better how to put the question sentence using either verb to do or verb to be. The results from test of learning in level 2 revealed that they learned how to identify the GIST or detail from listening. However, the test of learning was part of the reviewing of lesson trained and learned. The observing of behavioral changes pointed out that four consistent participants were those who really lack of confidence in using English and they wanted to improve themselves. They confidently spoke out more with a great improvement and able to produce full complete sentence in a longer conversation. Such improvement was noticeably due to pair work or group work designed in Phase II. So, the behavioral changes led to the interview to understand how/what they learn in classroom from pair work or group work. From the interview, they gave their opinion toward this training session that pair work helped them gain more confidence, while obtaining collaborative idea and action towards the work assignment in classroom helped them learn more to regulate their current knowledge and alter the proper one in their real work life. The excerpts from the interview with two participants who seemed to lack of confidences in speaking English at the very beginning of the course. They expressed how they were able to produce longer sentence and able to speak up with no more fear:

I think pair work is a helping hand from peers. It is not only just sharing work, but we learn from each other's thoughts. At the same time, our friends used some vocabularies I have never used before, then I realized, remembered and learned from them. I think I learned from listening and can imitate from peers.

I think everyone has got different background and knowledge and everyone can help. I can pair up 
with anyone, no specific. I learn something I have never known from pair-work, and I think I learned a lot from their experiences from Scroll team and from Motor team. What I leaned from peers I could apply when I Jabber or call direct to ITSS team on the emergency case.

The process of developing a training program narrated above were parts of the key findings of the researcher's Doctoral research and can be described as space allowed in this article. In the authentic situation of taking full responsibility in developing and implementing a training program, it was considered time consuming and continuous efforts from start until the end while further following up as post training assessment was also required. The trainer-researcher had obtained a great deal of professional development through these actions and operations and reflections undertaken during eight months from start of need analysis carried out through two phases of training program.

\subsection{The trainer-researcher professional development results}

Being an ingrained trainer-researcher could be challenging due to a lot of duties of both organizational role and a trainer-researcher role. The practices taken and the results occurred in the process during the research period assisted professional development which can be presented in three aspects and further discussion and conclusion will be presented in the final section.

Firstly, the trainer-researcher took full responsibilities in the training program. The trainer took program designer and trainer role who know best with what and how should be trained in the context and the researcher had the observation and critique roles for improvement and assessment of the program. Such practices support a better understanding of the fundamental in all the 'how to process' of every step. That basic knowledge is an experiential learning the researcher developed and can be applied in both organizational training and even in the tertiary / adult educational level.

Secondly, the novice trainer-researcher was able to reflect the training positive and negative results and managed her own adjusting and altering the proper training method, classroom environment and even her training style and mind set. The researcher was first thought of integrating all skills in one lesson within one-hour and it was not possible, the reflection made her mind set changed to consider minimizing all four skill but focusing on the key activity that induce the focused skill improvement.

Thirdly, the practice of adapting, adjusting and developing authentic material and spending amount of time looking for the proper teaching media tools such as YouTube clip or work-related article for reading practice, were the major professional development results obtained in the field of 'teaching global English' for the work context and global context (Selvi, 2017). Moreover, seeking for authentic topic for the context is valuable practice of teaching global English, it is a part of researcher's self-development as well.

\subsection{The trainer reflection}

The trainer's reflective journal was taken during qualitative data analysis and after every class-hour. The critical reflections on both positive and negative behavior as a trainer were valuable for a novice language trainer as it was used as a tool for improving and adjusting during the training process. The classroom management and anxiety management were challenging; too big class size of 20 learners in the Phase I reflected that the trainer must be well prepared with all factors: learners, contents and training and learning. As a trainer 'the coach style', the ability of sensing the learners' energy levels were important. The coach style orients both to learning, activities and to the learners' skill development, confidence building and application (Lawson, 2009). As a language trainer in the work context, a corrective feedback (CF) to adult learner was beneficial because it made the learner aware and noticed their input and production (Yoshida, 2008). The trainer attempted to give proper $\mathrm{CF}$ at the right pace, right time, on spot or later after the class by giving clues for corrections was considered vital.

\section{Summary}

This training- research aimed at exploring and developing an English literacy training program for the work context and in a specific workplace. The study is an infrequent case, so the researcher reviewed the background of how and why literacy and workplace literacy, specifically the English literacy plays important role in all generations and highly involves with educational system, academic level and not limit to the organizational or non-organizational sector. As a scarcity mentioned, the further literature review was based on specific related 
aspects pertaining the ADDIE model which is used as a training program development framework in the school grader level and in the university level. Other literatures related included the English skill needs in engineering profession internationally. It is widely accepted that engineering profession does not only need the hard skills but they need communication skill, especially English skills in which is used as global language and working language in the globalization era.

The finding reveals a long-haul process of developing an English training program from start of analyzing the needs throughout the completion of final process of evaluation. As novice trainer-researcher, the use of ADDIE model was to assure the most feasibility of pedagogical process. However, the critical finding and the most challenging perspective is the 'processing of or how to ....' of needs interpretation into content and instructional plan. For example: how to adapt a grammatical content into a simple instruction while selecting the applicable YouTube clip and activity for the class. The developing of a program for the work context is a careful process, as the participants are adult learner and they may resist any learning that they cannot apply in their real works. The selection of work-related topic resulted in a positive result for pair-work and group discussion which stimulate practicing and learning application. This finding also evidences the fact that improving literacy, the authenticity and the learner-centered are the key to enrich the training program.

The finding reflects the trainer-researcher professional development in three perspectives as mentioned. The thorough process also helps the researcher better control of taking reflective journal which is important part of the training program and the professional development. This study also enhances a great deal of trainer's ability and confidence in developing an English training program for adult learner in both of work context and in the academic context. This is due to the fact that the improvement in English literacy, should be induced in all generation, in communities and not limited to the workplace literacy in organization.

\subsection{Conclusion}

The attention of promoting literacy improvement throughout the world in the globalization era and as to address the rapid changes in the world of work while the multimodal literacy and complexity are increasingly required. The path to enhance literacy improvement via workplace literacy training program and collaboration between government and private organization sector, and specifically with the English literacy training program, the focus of the authenticity of the program and learner-centered are the key to empower participants and desirable outcomes. The authenticity is the concrete training program that address the real needs of real context in which the learner could apply their knowledge and skill learned when they are back at their work. This training-research, therefore; concludes that the developing of English literacy training program that focuses on practice-based of the real work content together with peer to peer learning interaction with the instruction guidance by the trainer from the same context has established proven result in learner learning process and application. The learners, as they have limited opportunity to practice using their English, yet the one-hour of concentrating on practicing is a valued learning. This could be contained that the balancing participants' class engagement more with the practice-based by giving more chances of practicing either via pair-work or small group work with some core contents of explicit instruction, later the following up state of consciously self-practicing during work hour would boost up more skill. This could be presumably said that engineer; as adult learner, they are experienced, motivated and have readiness to learning by doing (Charatwattananich, 2019).

The rigorous process of using the ISD: ADDIE model for developing the English literacy training program is a flexible systematic tool which can be purposefully applied to meet the developing objectives. Every step induced the trainer-researcher critically analyzed, synthesized, summarized information and strategized into the teaching and learning process. The Analysis step induced a careful qualitative analysis; the participants' words and affections mean essential elements to the training design. The crafting of the training program design balances the trainer-researcher's bias in preparing the pedagogic training program while the developing process immersed most of the overall training time to find the best complement materials for the specified contents. Nevertheless, it is a valuable investment that enhances learner learning process as well as professional development compare to the purely utilizing standard textbook or coursebook in classroom because the learners have avoided learning from textbook but life contents. The implementing of the training fully engaged the trainer-researcher to preoccupy with teaching, managing, observing, evaluating and mediating the classroom activities. As novice trainer-researcher, it comparatively assessed that the diversity class size of 20 learners as in Phase I, it was rather difficult to conduct the explicit instruction while keeping the classroom environment was rarely efficient. In contrast, the ideal practice-based class size of 6-8 learners as in Phase II raised up more effective training and the learners were brave to participate more. This analytically emphasizes that the learners' feeling of having a safe classroom condition 
(Derakhan, Tahery \& Mirarab, 2015) and a group cohesion truly promote their learning effort and motivation. The evaluation process affirms the learners' cognitive and affective results which the learner marked that learning many new things help fortify their speaking and writing skill practices. The learners' average marks of knowledge learned, they nonetheless understand from remedial instructions and they know why and how they will make it correct in their work. This is the true learning result that the trainer and the learner expect.

The trainer-researcher analytically expresses that being able to engage in every step including writing researcher's reflective journal and achieve the developing of an English training program for the workplace context from start throughout the accomplishment is a career growth as a trainer and professional development as a novice researcher. This could somehow answer a question, if any organization would realize that developing an inside English language trainer for their own employee would be worth as it supports purposes of employee development as well as essential language skills development in the trainer and the learner. Drawing the significance of this study, in fact, in professional development the learners have better understanding of learning English the way they could immediate use while the trainer-researcher have delved the way a novice could become a graduate language trainer and a researcher growth ladder.

\subsection{Recommendations}

According to the finding summary and conclusion drawn from the study, the recommendations were made in three viewpoints. First is a recommendation for replicating this training-research practice in the organization in order to develop their own English training program and the in-house English trainer who knows the insight and context. It may sound pedagogically bias, yet it could be good for the situation of limited training hour. It is suggested 'less is better' (McKeown, 2014), yet a proper follow up outside classroom should be helpful. Second viewpoint recommends that academic institute or the university level and industrial organization may work collaboratively to understand how to improve the English communication program that address the current skill gaps. This should become a critical agenda in this decade because Thailand needs a global engineer who can cope up with rapid technology alteration. Third viewpoint recommends that engineering profession should aware of the importance of English literacy advancement as it is a tool for lifelong learning for every engineer profession; lifelong learning dependent for its successful implementation on people's increasing ability and motivation to engage in selfdirected learning activities (Cropley, 1979).

\section{Acknowledgement}

The researcher would like to express my deep gratitude to both of my advisors, Asst. Prof. Dr. Janpanit Surasin, who has given me her kind motivation and elevated my research skills and to Asst. Prof. Dr. Panwalai Kewara of her helpful advice. A thankful to Emerson, the research site that given me job, experience in human resource field and a valuable chance to accomplish this research and thanks to the VP and HR manager who had accepted and acknowledged the importance of this research. Lastly, a thankful to the engineer participants who enthusiastically participated in the training program research, without them and their willingness to learn, this success would have not happened and wishing them all success in return.

\section{References}

ACTFL (2012) ACTFL proficiency guidelines 2012 Available at: https://www.actfl.org/sites/default/files/pdfs/public/ACTFLProficiencyGuidelines2012 FINAL.pdf (Accessed: 6 June, 2019)

Adoniou, M. (2016) Literacy standards aren't falling, but they are changing. Available at: https://theconversation.com/literacy-standards-arent-falling-but-they-are-changing-53626 (Accessed: December 18, 2017)

Bhattacharya, G. (1997) Literacy in the workplace. Available at: https://pdfs.semanticscholar.org/7d98/e709af7fc7dece6d77a2fbb44c610c0519a4.pdf (Accessed: January 1, 2016)

Branch, R.M. (2010) Instructional design: The ADDIE approach. New York, NY: Springer \& Business Media Brown, J., Taylor, M., McKenzie, P. and Perkins, K. (2015) Investing in workforce literacy pays: Building employer commitment to workplace language, Literacy and Numeracy Programs. Available at: https://research.acer.edu.au/cgi/viewcontent.cgi?article=1026\&context=transitions misc (Accessed: December 
18, 2018)

Charatwattananich, M. (2019) Developing an English literacy training program for engineering staff in Thailand. Unpublished PhD Thesis. Burapha University

Cropley, A.J. (ed.) (1979) Lifelong education: A stocktaking, Unesco Institute for Education, Hamburg, Germany: Werner A. Jensen

Crystal, D. (1997) English as a global language. Cambridge: Cambridge University Press.

Derakhshan A., Tahery, F., and Mirarab, N. (2015) Helping Adult and Young Learners to Communicate in Speaking Classes with Confidence. Mediterranean Journal of Social Sciences MCSER Publishing, Rome-Italy, Vol 6 No 2, March 2015, pp. 520-525.

Hiranrat, W., Ruksasuk, N., and Chaijaroen, S. (2016) The design of the contents of an E-Learning for teaching English language use ADDIE model. International Journal of Information and Education Technology, Vol. 6, No. 2, February 2016, pp. 127-131.

Holden, J.T. (2015) White paper: An introduction to the ADDIE instructional systems design model. Available at: https://www.scribd.com/document/350034046/White-Paper-Introduction-to-the-ADDIE-ISD-Model (Accessed: March 25, 2019)

InstructionalDesign.org (2019) ADDIE model. Available at: https://www.instructionaldesign.org/models/addie/ (Accessed: January 10, 2019)

Jurmo, P. (2004) Workplace literacy education definitions, purposes, and approaches. Focus on Basic Connecting Research and Practice. Volume 7, issue B, November 2004. Available at: http://ncsall.net/index.html@id=629.html (Accessed: December 11, 2017)

Kassim, H. and Ali, F. (2010) English communicative events and skills needed at the workplace:

Feedback from the industry. English for Specific Purposes Volume 29, Issue 3, July 2010, pp. 168-182.

Kitao, K. (1996) Why do we teach English? The Internet TESL Journal, Vol. II, No. 4, April 1996 Available at: http://iteslj.org/Articles/Kitao-WhyTeach.html (Accessed: December 4, 2017)

Kurt, S. (2017) Definitions of the Addie model Available at: https://educationaltechnology.net/definitions-addiemodel/ (Accessed: February 5,2019)

Lawson, K. (2009) The trainer's handbook (updated edition). San Francisco, CA: Pfeiffer

McKeown, G. (2014) Essentialism: The discipline pursuit of less. New York, USA: Crown Publishing Group

Molenda, M. (2015) In search of the elusive ADDIE model. Available at:

https://www.researchgate.net/profile/Michael Molenda/publication/251405713 In search of the elusive ADD IE model/links/5b5f098ba6fdccf0b200e5b2/In-search-of-the-elusive-ADDIE-model.pdf (Accessed: April 10, 2019).

Nichols Hess, A., and Greer, K. (2016) Designing for engagement: Using the ADDIE model to integrate highimpact practices into an online information literacy course. Communications in Information Literacy, 10 (2), pp. 264-282.

Patil, A.S. (2005) Global engineering Criteria for the development of the global engineering profession. World Transactions on Engineering and Technology Education, Vol.4, No.1, 2005, pp. 49-52.

Rajprasit, K., Pratoomrat, P., Wang, T., Kulsiri, S. and Hemchua, S. (2014) Use of the English language prior to and during employment: experiences and needs of Thai novice engineers. Global Journal of Engineering Education Volume 16, Number 1, 2014, pp. 27-33.

Riemer, M.J. (2002) English and communication skills for the global engineer. Global J. of Engng. Educ., Vol.6, No.1, Published in Australia, pp. 91-100.

Riamliw, J. (2013) Concepts of Literacy of Thai Foundation English Teachers: A national study. PhD thesis. University of Pittsburg. Available at: http://d-scholarship.pitt.edu/19055/1/RiamliwJ_2013ETD.pdf (Accessed: December 4, 2017)

Saldana, J. (2015) The coding manual for qualitative researchers. 3rd edn. Great Britain: SAGE

Selvi, A.F. (2017) 'Preparing teacher to teach English as an international language: Reflections from Northern Cyprus', in Matzuda, A. (ed.) Preparing teacher to teach English as an international language: New 
perspectives on language and education. Bristol: Multilingual Matters. chapter 8 .

Singapore Workforce Skills Qualifications (2017) Employability Skills WSQ. Available at:

https://www.ssg.gov.sg/wsq/wpl-wpn-wps.html?activeAcc=5 (Accessed: December 11, 2017).

Spence, P., and Liu, Gi-Zen. (2013) Engineering English and the high-tech industry: A case study of an English needs analysis of process integration engineers at a semiconductor manufacturing company in Taiwan. English for Specific Purposes, Volume 32, Issue 2, April 2013, pp. 97-109.

Sureeyatanapas, P., Boonma, A. and Thalangkan, S. (2016) English proficiency requirement for engineering graduates at private organization in Thailand. KKU Engineering Journal 2016, 43 (S1), pp. 35-39.

UNESCO (2005) 'Chapter 6 Understandings of literacy' in Education for All Global Monitoring Report 2006: Literacy for life, pp.147-159 Available at: http://www.unesco.org/education/GMR2006/full/chapt6 eng.pdf (Accessed: July 25, 2016).

UNESCO (2008) The Global literacy challenge: a profile of youth and adult literacy at the mid-point of the United Nations Decade 2003-2012. Available at: http://unesdoc.unesco.org/images/0016/001631/163170e.pdf (Accessed: July 19, 2016).

Yoshida, R. (2008) Learners' Perception of Corrective Feedback in Pair Work. Foreign Language Annual. Vol 41, No.3, pp. 525-541 